$1-1-1995$

\title{
Canopy arthropods at Fernow Experimental Forest in West Virginia's Allegheny Mountain section.
}

Linda Butler

Follow this and additional works at: https://researchrepository.wvu.edu/ wv_agricultural_and_forestry_experiment_station_bulletins

\section{Digital Commons Citation}

Butler, Linda, "Canopy arthropods at Fernow Experimental Forest in West Virginia's Allegheny Mountain section." (1995). West Virginia Agricultural and Forestry Experiment Station Bulletins. 713.

https://researchrepository.wvu.edu/wv_agricultural_and_forestry_experiment_station_bulletins/604 
Canopy Arthropods at Fernow Experimental Forest in West Virginia's Allegheny Mountain Section: II. Nacrolepidopterous Larvae on Foliage and

\section{Under Burlap Bands}

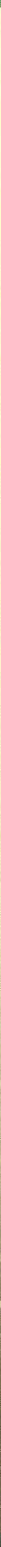


Authors

Linda Butler is Professor of Entomology and Vicki Kondo and Gregory Chrislip are Entomology Research Assistants, Division of Plant and Soil Sciences, College of Agriculture and Forestry, West Virginia University.

This research was supported by a grant from the USDA Forest Service. We would like to acknowlege the assistance and cooperation of the USDA Forest Service Appalachian Integrated Pest Management Program personnel, our undergraduate field and laboratory assistants and the data management assistance of Dr. Edwin Townsend.

West Virginia University

Agricultural and Forestry Experiment Station

College of Agriculture and Forestry

Rosemary Haggett, Director

Morgantown, WV 


\section{Canopy Arthropods at Fernow Experimental Forest in West Virginia's Allegheny Mountain Section: II. Macrolepidopterous Larvae on Foliage and Under Burlap Bands}

\section{Linda Butler, Gregory Chrislip and Vicki Kondo}

\section{INTRODUCTION}

In recent years, we have conducted a number of studies in West Virginia on species composition of the macrolepidoptera in canopies of hardwood forests. These studies have been for the collection of baseline data only (Butler 1992) and for the evaluation of impacts of gypsy moth suppression efforts (Butler and Kondo 1993; Sample et al. 1995).

In 1989 we began a study to evaluate non-target impact of the insect growth regulator Dimilin (1-(4 chlorophenyl)-3-(2, 6-diflubenzoyl) urea) or diflubenzuron on canopy arthropods. Dimilin has been applied to hundreds of thousands of acres in the United States for suppression of gypsy moth, Lymantria dispar (L.) (Lepidoptera: Lymantriidae) (USDA Forest Service 1990). From 1989 through 1994 we sampled canopy arthropods in four closed watersheds on the Fernow Experimental Forest near Parsons in the Allegheny Mountain section of West Virginia. In 1992 Dimilin was applied to two of the watersheds. Elsewhere we present results of impact of Dimilin on canopy arthropods and evaluation of macrolepidopterous moths sampled by blacklight trap. Here we present richness and abundance of macrolepidoptera larvae taken from foliage and collected from burlap bands on mixed birch (Betula spp.), black cherry (Prunus serotina Ehrh.), mixed maples (Acer spp.) and mixed oaks (Quercus spp.) during the sixyear study period. Used in this context, richness refers to number of species of larvae, abundance refers to total numbers.

\section{MATERIALS AND METHODS}

\section{Study Sites}

The Fernow Experimental Forest is located on the unglaciated Allegheny Plateau (latitude $39^{\circ} 05^{\prime} \mathrm{N}$, longitude $79^{\circ} 41^{\prime} \mathrm{W}$ ) at elevations ranging from 533 to $1,112 \mathrm{~m}$. The topography is rugged with slopes of 10 to 60 percent. The experimental forest encompasses 1,902 ha and has been divided into a series of water- 
sheds for research purposes. This study was conducted on watersheds 1, 4, 7, and 13.

Prior to establishment of the Fernow Experimental Forest (FEF) in 1934, the land was heavily cut between 1905 and 1910. Additional timbering occurred on several of the four watersheds from the early 1950s through the late 1970s. Currently the common tree species on the better sites include yellow-poplar (Liriodendron tulipifera L.), sugar maple (Acer saccharum Marsh.), black cherry, white ash (Fraxinus americana L.), American basswood (Tilia americana L.) and red oak (Quercus rubra L.). Dominant tree species on the poorer sites include various species of oak (Quercus spp.), hickory (Carya spp.), sourwood (Oxydendrum arboreum (L.) DC) and sassafras (Sassafras albidum (Nutt.) Nees) (Adams et al. 1993).

Importance values (IV) for tree species on watersheds 1, 4, 7, and 13 were determined by Stephenson 1992 (unpublished) in which he evaluated species on five small plots $\left(100 \mathrm{~m}^{2}\right)$ within each watershed, well away from watershed boundaries. All plants with stems greater than $2.5 \mathrm{~cm} \mathrm{DBH} \mathrm{(diameter} \mathrm{at} \mathrm{breast} \mathrm{height)}$ were considered to be trees. Individual tree species were given an importance value by adding the relative basal area plus relative density and dividing by two. Stephenson's importance values are used to characterize tree composition on the four watersheds that comprised this study.

Watershed 1 is 30.1 ha with a NE aspect. It has not been timbered since 1958. Tree species with the highest importance values were sugar maple, basswood, beech (Fagus grandifolia Ehrh.), black locust (Robinia pseudoacacia L.), cucumber magnolia (Magnolia acuminata L.) and red oak. Importance values for the four species groups sampled in this study were 29.2 for sugar maple, 2.6 and 1.5 for yellow birch (Betula lutea Michx. f.) and black birch (Betula lenta L.), respectively, and 3.7 for red oak. Red maple (Acer rubrum L.) and black cherry were sparse on watershed 1 .

Watershed 4 is 38.7 ha with an ESE aspect. Most abundant tree species with respect to importance values were beech, sugar maple, moosewood (Acer pensylvanicum L.), yellow-poplar, American basswood and red oak. Importance values for trees sampled in this study were 16.6 and 2.4 for sugar maple and red maple, respectively, 1.0 for black birch and 7.4 for red oak. Black cherry was represented on watershed 4 by a few large trees and abundant young trees in the understory, but the young trees were too small to have been counted in Stephenson's importance values. Watershed 4 is a relatively mature forest not having been timbered since 1910 .

Watershed 7 is 24.2 ha with an $\mathrm{E}$ aspect. It is the youngest of the forest stands, having been last cut and treated with herbicides in 1969. Most abundant species (IV) were black birch, sugar maple, red oak, and yellow-poplar. Importance values of trees sampled in this study were 15.4 for sugar maple, 9.2 for red oak, 33.3 for black birch and 8.4 for black cherry. 
Watershed 13 is 14.2 ha with a NNE aspect. Light-selective timbering of this watershed occurred until 1960, but it is a relatively mature stand. Predominant species (IV) were sugar maple, red oak, yellow-poplar, black cherry and black birch. Importance values for species utilized in this study were 30.5 for sugar maple, 1.1 for red maple, 29.3 for red oak, 6.4 for black birch and 6.6 for black cherry.

\section{Sampling Methods}

We began sampling macrolepidopterous larvae on all four watersheds in 1989 by means of burlap banding of trees and pole pruning of foliage.

Burlap bands $24 \mathrm{~cm}$ wide were stapled at breast height to trees. Ten trees each of black birch and black cherry were banded in late April 1989 on all four watersheds. Ten mixed maples were added on each watershed on July 5, 1989. Ten mixed oaks per watershed were added in early May 1990, giving a total of 160 banded trees for the study. Each year bands were installed in late April and sampling was begun early to mid-May: May 4, 1989; May 14, 1990; May 6, 1991; May 11, 1992; May 10, 1993; and May 9, 1994. Bands were left in place until early to mid-August each year and then removed after the last sampling date: August 15, 1989; August 13, 1990; August 12, 1991; August 10, 1992; August 9, 1993; and August 8, 1994. Each week all bands were checked and all macrolepidoptera larvae removed and returned to the laboratory for identification to species. Burlap bands mimic naturally occurring bark flaps and provide a refuge for sampling caterpillars that move up and down the trunks.

The first foliage samples were taken May 17, 1989 and consisted of two 25branch tip samples of mixed birch (black and yellow) and two of black cherry on each of the four watersheds, for a total of 16 samples per sampling date. On June 27, 1989 a similar sampling procedure was added for mixed maple (sugar and red) so that 24 samples were being taken for the remainder of the season. Sampling of mixed oak (primarily red oak) was added at the beginning of the 1990 sampling season, giving a total of 32 samples of foliage on each sampling date.

Foliage sampling was begun soon after leaf expansion each spring: May 17, 1989; May 15, 1990; May, 7, 1991; May 12, 1992; May 11, 1993; and May 8, 1994 and was continued until mid-August each year. During the six years of the study, foliage samples were taken each week for a total of 15 sampling dates each season. Foliage was collected from low- to mid-canopy with pole pruners that were equipped with large plastic catch bags to collect the foliage that fell.

The 32 foliage samples of mixed birch, black cherry, mixed maple and mixed oak were returned to the laboratory where all macrolepidoptera larvae were removed and identified to species by spot identification, comparison with voucher specimens in the WVU Arthropod Collection, comparison with color slides of macrolepidoptera prepared in our laboratory or by rearing the larva to the adult moth for positive identification. 
After larvae were removed, all leaves were removed from twigs in each sample, placed in paper bags, oven dried, and weighed. Samples averaged about 50 grams dry leaf weight.

On May 16, 1992, Dimilin 4L was applied to watersheds 1 and 13 at a rate of $0.5 \mathrm{oz} . \mathrm{AI} / \mathrm{acre}$. Elsewhere we will discuss impact of that treatment on macrolepidopterous larvae. Here we present overall richness and abundance of larvae during the six-year study on the Fernow and present information on seasonal range and host associations.

Voucher specimens from the study are deposited in the WVU Arthropod Collection. Species are listed according to the checklist given by Hodges et al. (1983).

\section{RESULTS}

A total of 86 species of macrolepidopterous larvae representing 10 families was taken from bands and 111 species from 13 families were collected on foliage from 1989 through 1994 (Table 1). Most larvae collected by both methods were Noctuidae and Geometridae. Under bands, noctuid richness (39 species) was highest with geometrids contributing 24 species. On foliage geometrid richness (43 species) was highest with noctuids representing 36 species. The third richest family was Notodontidae with 12 species on foliage and 6 species under bands. While more families of macrolepidoptera were taken on foliage, sampling by bands allowed evaluation of several species not encountered on foliage, particularly with noctuids and arctiids (Table 1 ).

The most abundant larva under bands was the gypsy moth Lymantria dispar (Table 2). When the study began in 1989 almost no L. dispar were found, but their numbers gradually built up and became noticeably abundant by 1994. Not unexpected was the fact that most gypsy moth larvae were found under bands of oaks, their preferred hosts. Of the remaining species of larvae the most abundant were the noctuids Polia latex (Gn.), Orthosia rubescens (Wlk.), Abagrotis alternata (Grt.), Lithophane hemina Grt., L. innominata (Sm.) and Zale minerea (Gn.) and the lasiocampids Malacosoma disstria $\mathrm{Hbn}$. and M. americanum (F.).

Since burlap bands mimic bark flaps on trees and provide insects with shelter, associating a species of caterpillar with a specific host food tree on the basis of catches under bands is problematic. Many of the species taken under bands are herbivorous on a number of deciduous host trees (Table 2). This is reflected by relatively even numbers of larvae for the host species groups; examples of generalists include Orthosia rubescens, Lithophane hemina and Malacosoma disstria. Polia latex is considered a generalist (Wood and Butler 1989) but it was taken in much greater abundance under bands on cherry trees in this study. Abagrotis alternata is a general feeder on many tree species (Forbes 1954) but frequently feeds on blueberry (Vaccinium spp.) and other low woody plants and 
climbs trees to seek shelter. Malacosoma americanum strongly prefers black cherry but was found commonly under bands of all tree species in the study.

Most species of larvae recorded from tree bands in this study were in very low numbers. Sixty-one of the 86 species were represented by fewer than 20 individuals over the six-year period and 25 species were recorded as single individuals.

Species of macrolepidopterous larvae taken from foliage of the four tree species groups are listed in Table 3. Five species of geometrid larvae were the most abundant: Lomographa glomeraria (Grt.), Erannis tiliaria (Harr.), L. vestaliata (Gn.), Melanolophia canadaria (Gn.) and Alsophila pometaria (Harr.). Two noctuids, Orthosia hibisci (Gn.) and Polia latex, were next most abundant. Of the 17 species represented by more than 100 individuals during the study, 10 were geometrids, 6 were noctuids and one was a lymantriid, the gypsy moth.

Several of the more abundant species are generalists on a number of tree species: Erannis tiliaria, Melanolophia canadaria, Alsophila pometaria, Orthosia hibisci and Polia latex, for example. Erannis tiliaria and A. pometaria tend to be outbreak species (Butler 1985), but their numbers were stable and generally low at the FEF.

A number of species showed strong food tree preferences. Lomographa glomeraria, L. vestaliata, L. semiclarata (Wlk.), and Hydria prunivorata (Fgn.) are black cherry feeders; Itame pustularia (Gn.) and Symmerista leucitys Franc. feed on maple and Catocala ilia (Cram.) feeds on oak.

Seventy-one of the 111 species on foliage were represented by fewer than 20 individuals; 16 species were represented by a single caterpillar.

The highest richness of larvae on foliage was recorded for mixed oak with 72 species (Table 4). Black cherry accounted for 71 species and had the greatest abundance of larvae at 3,188 , primarily because of the large numbers of Lomographa spp. Identical species richness ( 57 species) was noted for black birch and mixed maple. Abundance of larvae was similar among black birch, mixed maple and mixed oak (Table 4). Gypsy moth larvae accounted for 284 of the 1,387 individuals on oak.

Dates of first collection and last collection are given for all species of caterpillars under bands and on foliage (Tables 2, 3). Some larvae occurred throughout most of the May-August period and represent species that are univoltine and abundant, but are not highly synchronized for dates of moth emergence and oviposition. Therefore larvae are hatching over a several week period; Polia latex and Morrisonia confusa (Hbn.) are examples. Long collection periods are also expected for multivoltine species (species with more than one generation per year), such as the geometrids Melanolophia canadaria and Lomographa vestaliata. Species that are more restricted to a portion of the season include the spring defoliating geometrids and noctuids such as Erannis tiliaria, Alsophila pometaria and Orthosia hibisci. 


\section{DISCUSSION}

A total of 130 species of macrolepidopterous larvae were identified during this study (86 from bands and 111 from foliage). Richness and abundance of macrolepidopterous caterpillars are comparable to that reported from other recent studies in West Virginia (Butler 1992; Butler et al. 1995a).

In 1984 and 1985 a baseline study was conducted at Coopers Rock State Forest in which 100 species of macrolepidopterous larvae in 14 families were identified from foliage of the same four tree species groups utilized in the Fernow study. A higher number of species of both noctuids and geometrids primarily accounts for the greater overall richness in the Fernow study.

Ninety-one species of macrolepidopterous caterpillars from 10 families were identified from oak foliage in the Bacillus thuringiensis kurstaki (Btk) non-target impact study conducted in Pendleton and Grant counties in West Virginia's Eastern Ridge and Valley section in 1990-1992 (Sample et al. 1995; Butler et al. 1995a). The 91 species on oak alone is considerably higher than the 61 species on oak at Coopers Rock and the 72 species on oak at Fernow; however, the sampling intensity of oak in the Btk study exceeded that of the Coopers Rock and current study by 2-3 fold. Table 3 indicates the species taken in the current study that were not represented at one or both sites of the two earlier studies. The comparison for Grant and Pendleton counties includes only those oak species for which oak is an expected host.

Coopers Rock and Fernow are both within West Virginia's Allegheny Mountain section and we might expect the caterpillar fauna to be similar. The 38 species taken on foliage at Fernow but not at Coopers Rock include 15 species of geometrids, 18 species of noctuids, a lasiocampid, a notodontid, a lycaenid, and two nymphalids (Table 3). We note that the Coopers Rock study was conducted for two years and the Fernow study for six, but during each year, samples were collected until October at Coopers Rock but only until mid-August at Fernow. Twenty-four of the 38 species not collected at Coopers Rock were represented at Fernow by three or fewer individuals over the six years. One would expect that species that are in very low abundance may have been taken at Coopers Rock with either greater sampling intensity during each of the two years, or by extending the study for more years. All of the 38 species not taken at Coopers Rock are expected to be there with the possible exception of the noctuid Copipanolis styracis (Gn.), which has only been collected commonly in the more eastern oak-pine habitats of the state (Butler et al. 1995a).

Species taken at Coopers Rock that were not represented at Fernow include the hesperiid Erynnis juvenalis (F.); the geometrids Semiothisa aemulataria (Wlk.), Paleacrita merriccata Dyar and Anagoga occiduaria (Wlk.); the apatelodid Apatelodes torrefacta (J.E. Smith); the saturniids Eacles imperialis (Drury), Anisota senatoria (J.E. Smith), Automeris io (F.), Antheraea polyphemus (Cram.), 
Callosamia promethea (Drury) and Callosamia angulifiera (Wlk.); the notodontids Hyperaeschra georgica (H.-S.) and Oligocentria lignicolor (Wlk.); the arctiids Halysidota harrisii Walsh and Lophocampa caryae Harr.; and the noctuids Panopoda rufimargo (Hbn.), Cerma cerintha (Tr.), Acronicta increta Morr., A. inclara Sm., A. retardata (Wlk.), A. impleta Wlk., Phosphila turbulenta $\mathrm{Hbn}$. and Himella intractata (Morr.). All of these species were taken at Coopers Rock in very low numbers and/or late in the season, i.e., August-October when samples were not taken at Fernow.

Eighty-six species of macrolepidopterous larvae were taken from bands at Fernow from 1989-1994. In a Dimilin impact study at Coopers Rock in 1990 and 1991, 42 species of larvae representing eight families were taken from bands (Butler and Kondo 1993). The Coopers Rock study employed 80 banded trees from mid-April until mid-September each of the two years in comparison with 160 banded trees evaluated from mid-May until mid-August for six years at Fernow. Some similar results are noted with respect to the composition of the most abundant species. At both sites, the gypsy moth, Lymantria dispar was most abundant. Polia latex, which was second most abundant at Fernow, was third most abundant at Coopers Rock. Other examples of more abundant species at Fernow are ranked with comparisons of rank for species at Coopers Rock: Orthosia rubescens (3 versus 16), Abagrotis alternata (4 versus 2), Lithophane hemina (5 versus 19), Malacosoma disstria (6 versus 14), Zale minerea (8 versus 21), and Malacosoma americanum (9 versus 10). Lithophane innominata, the seventh most abundant species at Fernow, was not taken under bands at Coopers Rock.

Relatively abundant species taken at Coopers Rock that were relatively less abundant at Fernow include Orthosia hibisci (number 4 at Coopers Rock, number 15 at FEF), Halysidota tesselaris (J.E. Smith) (5 versus 24), Epiglaea decliva (Grt.) (6 versus 14), Orgyia leucostigma (J.E. Smith) (7 versus 36), Polia nimbosa (Gn.) (8 versus 60), Dasychira basiflava (Pack.) (9 versus 32) and Dasychira dorsipennata (B. \& McD.) (11 versus 28). The noctuid Polia detracta (Wlk.) was the only species taken under bands at Coopers Rock that was not represented either under bands or on foliage at Fernow.

During 1990-1994 we sampled macrolepidopterous moths on the four watersheds at Fernow by means of blacklight traps (Butler et al. 1995b). The most abundant moths were Itame pustularia, Hydrelia inornata (Hulst), Lomographa glomeraria, L. vestaliata, Halysidota tesselaris, Probole amicaria (H.-S.), Melanolophia canadaria and Iridopsis larvaria (Gn.). Five of the 12 most abundant larval species on foliage are represented here in this group.

A total of 376 species of macrolepidopterous moths was collected at Fernow (Butler et al. 1995b); in this paper we have listed 130 species of larvae on four host plant groups. Some species of moths were not represented in larval collections because we did not sample the appropriate host. For example, Euphyia 
unangulata (Haw.) larvae feed on chickweed (Forbes 1948), and Clemensia albata Pack. larvae feed on dead leaves (Forbes 1960). A number of species of larvae were collected that were not represented as adults in light traps, for example, Erannis tiliaria and Alsophila pometaria, whose males fly in November (females are flightless) and Phigalia titea, whose males fly in March (females are flightless).

This six year study of macrolepidopterous larvae on foliage and under tree bands at Fernow resulted in the identification of 130 species of larvae on the study plots, indicating a high diversity of species.

\section{SUMMARY}

Macrolepidopterous larvae were collected from foliage and bands of black birch, black cherry, mixed maples and mixed oaks from May-August 1989-1994. Collections resulted in 130 species of larvae. No species were sufficiently abundant to be considered in outbreak mode, although gypsy moth larval populations were building in the watersheds. Little defoliation was evident. While foliage pruning and tree banding produced 111 and 86 species of larvae respectively, the sampling methods complement each other for evaluating species richness.

\section{LITERATURE CITED}

Adams, M.B., J.N. Kochenderfer, F. Wood, T.R. Angradi and P. Edwards. 1993. Forty years of hydrometerological data from the Fernow Experimental Forest, West Virginia. USDA Forest Service. Gen. Tech. Rpt. NE-184. 24 pp.

Butler, L. 1985. Biology of the half-wing geometer, Phigalia titea Cramer (Geometridae), as a member of a looper complex in West Virginia. J. Lepidop. Soc. 39:177-186.

Butler, L. 1992. The community of macrolepidopterous larvae at Coopers Rock State Forest, West Virginia: a baseline study. Can. Entomol. 124:1149-1156.

Butler, L. and V. Kondo. 1993. Impact of Dimilin on non-target Lepidoptera: Results of an operational gypsy moth suppression program at Coopers Rock State Forest, West Virginia. WV Agric. and For. Exp. Sta. Bull. 710.21 pp.

Butler, L., C. Zivkovich, and B.E. Sample. 1995a. Richness and abundance of arthropods in the oak canopy of West Virginia's Eastern Ridge and Valley Section during a study of impact of Bacillus thuringiensis with emphasis on macrolepidoptera larvae. WV Agric. and For. Exp. Sta. Bull. 711. 
Butler, L., V. Kondo, and G. Chrislip. 1995b. Canopy arthropods at Fernow Experimental Forest in West Virginia's Allegheny Mountain Section: I. Macrolepidopterous moths collected by blacklight trap during a Dimilin impact study. WV Agric. and For. Exp. Sta. Bull. 712.17 pp.

Forbes, W.T.M. 1948. Lepidoptera of New York and Neighboring States, Part II, Cornell University Agriculture Experiment Station Memoir 274; 263 pp.

Forbes, W.T.M. 1954. Lepidoptera of New York and Neighboring States, Part III, Cornell University Agriculture Experiment Station Memoir 329; 433 pp.

Forbes, W.T.M. 1960. Lepidoptera of New York and Neighboring States, Part IV, Cornell University Agriculture Experiment Station Memoir 371; 188 pp.

Hodges, R.W., T. Dominic, D.R. Davis, D.C. Ferguson, J.G. Franclemont, E.G. Munroe, and J.A. Powell. 1983. Checklist of the Lepidoptera of America North of Mexico. London. E.W. Classey Ltd. and Washington, D.C. Wedge Entomol. Res. Found. $284 \mathrm{pp}$.

Sample, B.E., L. Butler, C. Zivkovich, R.C. Whitmore, and R. Reardon. 1995. Effects of Bacillus thuringiensis and defoliation by the gypsy moth on native arthropods. Can. Entomol. (Accepted).

Stephenson, S.L. 1992. Department of Biology, Fairmont State College, Fairmont, West Virginia. Personal Communication.

USDA Forest Service. 1990. Gypsy moth news. 24.

Wood, P.S. and L. Butler. 1989. Biology of Polia latex (Guenee) (Noctuidae) with descriptions of eggs and larvae. J. Lepidop. Soc. 43:299-304. 
TABLE 1.

Distribution of species of macrolepidopterous larvae by family; number of species of larvae collected from tree foliage and from tree bands at the Fernow Experimental Forest, WV 1989-1994.

\begin{tabular}{lcc}
\hline Family & Foliage & Bands \\
\hline Papilionidae & 1 & 1 \\
Lycaenidae & 2 & 1 \\
Nymphalidae & 2 & 0 \\
Thyatiridae & 1 & 1 \\
Drepanidae & 1 & 0 \\
Geometridae & 43 & 24 \\
Lasiocampidae & 2 & 2 \\
Saturniidae & 3 & 0 \\
Sphingidae & 1 & 2 \\
Notodontidae & 12 & 6 \\
Arctiidae & 2 & 5 \\
Lymantriidae & 5 & 5 \\
Noctuidae & 36 & 39 \\
\hline TOTAL & 111 & 86 \\
\hline
\end{tabular}

TABLE 2

Macrolepidopterous larvae under bands of four host tree groups at the Fernow Experimental Forest, West Virginia. Species are arranged from most to least abundant for the combined sampling years of 1989-1994. First and last collection dates are given.

\begin{tabular}{|c|c|c|c|c|c|c|c|c|}
\hline \multirow[b]{2}{*}{ Species } & \multirow[b]{2}{*}{ Family $^{1}$} & \multicolumn{5}{|c|}{ No. per host tree } & \multicolumn{2}{|c|}{ Collection Dates } \\
\hline & & Birch & Cherry & Maple & Oak & Total & First & Last \\
\hline Lymantria dispar (L.) & LYM & 734 & 550 & 878 & 2267 & 4429 & 06MAY & 13AUG \\
\hline olia latex (Gn.) & NOC & 138 & 402 & 100 & 98 & 738 & & $15 \mathrm{AUG}$ \\
\hline Orthosia rubescens (Wlk.) & NOC & 107 & 197 & 46 & 135 & & IAY & 04JUL \\
\hline Abagrotis alternata (Grt.) & $\mathrm{NOC}$ & 39 & 40 & 32 & 108 & & & $27 J U N$ \\
\hline Lithophane hemina Grt. & NO & 64 & 4 & 66 & 28 & & AY & 23JUL \\
\hline Malacosoma disstria $\mathrm{Hbn}$. & LAS & 10 & 60 & 24 & 38 & & 09MAY & 22JUN \\
\hline Lithophane innominata (Sm.) & $\mathrm{NOC}$ & 21 & 24 & 59 & 9 & 113 & 06JUN & $11 \mathrm{JUL}$ \\
\hline Zale minerea $(\mathrm{Gn})$. & $\mathrm{NOC}$ & 7 & 68 & 20 & 8 & 103 & & 13AUG \\
\hline Malacosoma americanum (F.) & LAS & 24 & 46 & 17 & 10 & 97 & & 04JUL \\
\hline Erannis tiliaria (Harr.) & GEO & 11 & 15 & 17 & 27 & 70 & 13MAY & $29 J U N$ \\
\hline Catocala ultronia (Hbn.) & NOC & 9 & 50 & 7 & 2 & 68 & 17MAY & 12JUL \\
\hline Melanolophia c & GEO & 13 & 9 & 11 & 25 & & 06MAY & $10 \mathrm{AUG}$ \\
\hline Hyphantria cunea (Drury) & ARC & 11 & 24 & 6 & 9 & & 24JUN & $12 \mathrm{AUG}$ \\
\hline Epiglaea decliva (Grt.) & NOC & 8 & 10 & 14 & 11 & 43 & 06MAY & $07 \mathrm{JUN}$ \\
\hline Orthosia hibisci (Gn.) & NOC & 15 & 9 & 6 & 11 & 41 & $18 \mathrm{MAY}$ & 13JUL \\
\hline Acronicta hasta Gn. & NOC & 2 & 33 & 2 & 0 & 37 & $28 \mathrm{JUN}$ & $15 \mathrm{AUG}$ \\
\hline
\end{tabular}




\begin{tabular}{|c|c|c|c|c|c|c|c|c|}
\hline \multirow[b]{2}{*}{ Species } & \multirow[b]{2}{*}{ Family $^{1}$} & \multicolumn{5}{|c|}{ No. per host tree } & \multicolumn{2}{|c|}{ Collection Dates } \\
\hline & & Birch & Cherry M & Maple & Oak & Total & First & Last \\
\hline Alsophila pometaria (Harr.) & GEO & 4 & 9 & 5 & 18 & 36 & 06MAY & 08JUN \\
\hline Dasychira obliquata (G. \& R.) & LYM & 4 & 10 & 11 & 10 & 35 & 06MAY & 05AUG \\
\hline Itame pustularia (Gn.) & GEO & 2 & 4 & 11 & 17 & 34 & O9MAY & $21 \mathrm{JUN}$ \\
\hline Phigalia titea (Cram.) & GEO & 8 & 6 & 10 & 7 & 31 & 13MAY & $18 \mathrm{JUN}$ \\
\hline Phoberia atomaris $\mathrm{Hbn}$. & NOC & 0 & 6 & 1 & 22 & 29 & 20MAY & $12 J U L$ \\
\hline Catocala ilia (Cram.) & NOC & 1 & 2 & 0 & 24 & 27 & 06MAY & 09AUG \\
\hline $\begin{array}{l}\text { Hypoprepia fucosa Hbn. } \\
\text { Halusidoto tessellaris }\end{array}$ & ARC & 5 & 2 & 6 & 8 & 21 & 09MAY & 01AUG \\
\hline (J.E. Smith) & ARC & 4 & 2 & 4 & 10 & 20 & $17 J U N$ & 13AUG \\
\hline Amphipyra pyramidoides $\mathrm{Gn}$. & NOC & 5 & 4 & 5 & 6 & 20 & 21MAY & $15 \mathrm{AUG}$ \\
\hline Catocala amica (Hbn.) & NOC & 1 & 7 & 5 & 5 & 18 & 03JUN & 19JUL \\
\hline Crocigrapha normani (Grt.) & NOC & 4 & 11 & 1 & 0 & 16 & $20 \mathrm{JUN}$ & 19JUL \\
\hline \multicolumn{9}{|l|}{ Dasychira dorsipennata } \\
\hline (B. \& McD.) & LYM & 2 & 3 & 4 & 3 & 12 & 28MAY & 23JUL \\
\hline Lomographa vestaliata (Gn.) & GEO & 5 & 3 & 0 & 2 & 10 & 25MAY & $10 \mathrm{AUG}$ \\
\hline Lomographa glomeraria (Grt.) & GEO & 0 & 4 & 2 & 4 & 10 & 20MAY & $27 \mathrm{JUN}$ \\
\hline Lithophane laticinerea Grt. & NOC & 5 & 1 & 1 & 2 & 9 & 24MAY & 21JUN \\
\hline Dasychira basiflava (Pack.) & LYM & 2 & 3 & 2 & 1 & 8 & 06MAY & $12 \mathrm{AUG}$ \\
\hline Satyrium calanus $(\mathrm{Hbn})$. & LYC & 0 & 1 & 2 & 4 & 7 & 28MAY & $17 \mathrm{JUN}$ \\
\hline Papilio glaucus L. & PAP & 1 & 1 & 1 & 2 & 5 & $10 J U N$ & $12 \mathrm{JUL}$ \\
\hline Hydrelia inornata (Hulst) & GEO & 1 & 2 & 2 & 0 & 5 & 08JUL & 15JUL \\
\hline \multicolumn{9}{|l|}{ Orgyia leucostigma } \\
\hline (J.E. Smith) & LYM & 0 & 0 & 3 & 2 & 5 & $10 J U N$ & 01JUL \\
\hline Bomolocha baltimoralis (Gn.) & NOC & 0 & 0 & 4 & 1 & 5 & 30MAY & 09AUG \\
\hline Lithophane grotei Riley & NOC & 3 & 0 & 1 & 1 & 5 & 30MAY & $12 J U L$ \\
\hline Epimecis hortaria (F.) & GEO & 1 & 2 & 1 & 0 & 4 & 06MAY & $12 J U L$ \\
\hline Hypagyrtis unipunctata (Haw.) & GEO & 1 & 2 & 0 & 1 & 4 & 23MAY & $13 \mathrm{AUG}$ \\
\hline Zale lunifera (Hbn.) & NOC & 0 & 4 & 0 & 0 & 4 & 20MAY & $16 \mathrm{JUL}$ \\
\hline Achatia distincta $\mathrm{Hbn}$. & NOC & 1 & 2 & 0 & 1 & 4 & $24 J U N$ & 13JUL \\
\hline Morrisonia confusa (Hbn.) & NOC & 2 & 2 & 0 & 0 & 4 & 13MAY & $15 \mathrm{AUG}$ \\
\hline Lambdina fiscellaria $(\mathrm{Gn})$. & GEO & 0 & 1 & 0 & 2 & 3 & 01JUL & 15JUL \\
\hline Paonias myops (J.E. Smith) & SPH & 1 & 1 & 0 & 1 & 3 & 01JUL & $15 \mathrm{JUL}$ \\
\hline & NOC & 1 & \multicolumn{3}{|c|}{ Pseudothyatira } & 3 & 23MAY & 20JUN \\
\hline cymatophoroides (Gn.) & THY & 2 & 0 & 0 & 0 & 2 & 08JUL & 05AUG \\
\hline Phigalia strigataria (Minot) & GEO & 0 & 1 & 0 & 1 & 2 & 20MAY & $25 \mathrm{MAY}$ \\
\hline \multicolumn{9}{|l|}{ Lomographa semiclarata } \\
\hline \multirow{2}{*}{\multicolumn{8}{|c|}{ Lambdina pellucidaria }} & 01AUG \\
\hline $\begin{array}{l}\text { Lambdina pellucidaria } \\
\text { (G. \& R.) }\end{array}$ & GEO & & & & & & & \\
\hline Tetracis cachexiata $\mathrm{Gn}$. & GEO & 0 & 1 & 0 & 1 & 2 & 03JUN & 25JUL \\
\hline \multicolumn{9}{|l|}{ Eutrapela clemataria } \\
\hline (J.E. Smith) & GEO & 1 & 0 & 0 & 1 & 2 & 28MAY & 08JUL \\
\hline
\end{tabular}




\begin{tabular}{|c|c|c|c|c|c|c|c|c|}
\hline \multirow[b]{2}{*}{ Species } & \multirow[b]{2}{*}{ Family ${ }^{1}$} & \multicolumn{5}{|c|}{ No. per host tree } & \multicolumn{2}{|c|}{ Collection Dates } \\
\hline & & Birch & Cherry & Maple & Oak & Total & First & Last \\
\hline Schizura unicornis (J.E. Smith) & h) NOT & 0 & 2 & 0 & 0 & 2 & $18 J U N$ & $12 \mathrm{AUG}$ \\
\hline Parallelia bistriaris $\mathrm{Hbn}$. & $\mathrm{NOC}$ & 0 & 0 & 2 & 0 & 2 & 01JUL & $30 \mathrm{JUL}$ \\
\hline Acronicta fragilis $\mathrm{Gn}$. & $\mathrm{NOC}$ & 0 & 0 & 1 & 1 & 2 & 15JUL & $30 \mathrm{JUL}$ \\
\hline Alypia octomaculata (F.) & NOC & 1 & 1 & 0 & 0 & 2 & 01JUL & 01AUG \\
\hline Phlogophora periculosa $\mathrm{Gn}$. & $\mathrm{NOC}$ & 1 & 1 & 0 & 0 & 2 & $17 \mathrm{MAY}$ & 31MAY \\
\hline Lithophane unimoda (Lint.) & NOC & 0 & 2 & 0 & 0 & 2 & 31MAY & 31MAY \\
\hline Eupsilia vinulenta (Grt.) & $\mathrm{NOC}$ & 1 & 0 & 0 & 1 & 2 & 24MAY & 24MAY \\
\hline Polia nimbosa (Gn.) & NOC & 0 & 1 & 1 & 0 & 2 & 06MAY & 14MAY \\
\hline Himella intractata (Morr.) & NOC & 0 & 1 & 0 & 1 & 2 & $20 J U N$ & $20 \mathrm{JUN}$ \\
\hline Protoboarmia porcelaria (Gn.) & GEO & 0 & 0 & 0 & 1 & 1 & $26 \mathrm{JUL}$ & 26JUL \\
\hline Selenia kentaria (G. \& R.) & GEO & 1 & 0 & 0 & 0 & 1 & $27 \mathrm{JUN}$ & $27 \mathrm{JUN}$ \\
\hline Probole amicaria (H.-S.) & GEO & 0 & 0 & 0 & 1 & 1 & 05AUG & 05AUG \\
\hline Eulithis diversilineata (Hbn.) & GEO & 0 & 1 & 0 & 0 & 1 & 01JUL & 01JUL \\
\hline Hydria prunivorata (Fgn.) & GEO & 0 & 1 & 0 & 0 & 1 & $25 \mathrm{MAY}$ & 25MAY \\
\hline Hydrelia condensata (Wlk.) & GEO & 0 & 0 & 1 & 0 & 1 & 08AUG & 08AUG \\
\hline Eupithecia herefordaria C. \& S. & GEO & 0 & 0 & 1 & 0 & 1 & 07JUN & $07 \mathrm{JUN}$ \\
\hline Cladara atroliturata (Wlk.) & GEO & 0 & 0 & 1 & 0 & 1 & 06JUN & 06JUN \\
\hline Darapsa myron (Cram.) & $\mathrm{SPH}$ & 0 & 1 & 0 & 0 & 1 & 04JUL & 04JUL \\
\hline Nadata gibbosa (J.E. Smith) & NOT & 0 & 0 & 0 & 1 & 1 & 02AUG & 02AUG \\
\hline Symmerista leucitys Franc. & NOT & 0 & 0 & 1 & 0 & 1 & 08AUG & 08AUG \\
\hline Macrurocampa marthesia & & & & & & & & \\
\hline (Cram.) & NOT & 0 & 0 & 0 & 1 & 1 & 15JUL & 15JUL \\
\hline Heterocampa guttivitta (Wlk.) & NOT & 0 & 0 & 0 & 1 & 1 & 29JUL & 29JUL \\
\hline Lochmaeus manteo Doubleday & NOT & 0 & 0 & 1 & 0 & 1 & $15 \mathrm{JUL}$ & $15 \mathrm{JUL}$ \\
\hline Ecpantheria scribonia (Stoll) & ARC & 0 & 0 & 0 & 1 & 1 & $30 \mathrm{MAY}$ & 30MAY \\
\hline Lophocampa caryae Harr. & $\mathrm{ARC}$ & 0 & 0 & 1 & 0 & 1 & 05AUG & 05AUG \\
\hline Idia julia (B. \& McD.) & $\mathrm{NOC}$ & 0 & 0 & 1 & 0 & 1 & 09JUL & 09JUL \\
\hline Idia scobialis (Grt.) & NOC & 0 & 0 & 1 & 0 & 1 & $10 J U N$ & $10 \mathrm{JUN}$ \\
\hline Zale lunata (Drury) & NOC & 0 & 1 & 0 & 0 & 1 & 09JUL & 09JUL \\
\hline Acronicta americana (Harr.) & NOC & 0 & 0 & 1 & 0 & 1 & 09AUG & 09AUG \\
\hline Acronicta innotata $\mathrm{Gn}$. & NOC & 1 & 0 & 0 & 0 & 1 & $12 \mathrm{AUG}$ & $12 \mathrm{AUG}$ \\
\hline Acronicta lobeliae $\mathrm{Gn}$. & $\mathrm{NOC}$ & 0 & 0 & 0 & 1 & 1 & $17 \mathrm{JUN}$ & $17 \mathrm{JUN}$ \\
\hline Eudryas grata (F.) & NOC & 1 & 0 & 0 & 0 & 1 & $12 \mathrm{AUG}$ & $12 \mathrm{AUG}$ \\
\hline Eutolype rolandi Grt. & $\mathrm{NOC}$ & 1 & 0 & 0 & 0 & 1 & 21JUN & $21 J U N$ \\
\hline Psaphida resumens Wlk. & NOC & 0 & 1 & 0 & 0 & 1 & 01JUN & 01JUN \\
\hline
\end{tabular}

${ }^{1} \mathrm{LYM}=$ Lymantriidae, $\mathrm{NOC}=$ Noctuidae, $\mathrm{LAS}=$ Lasiocampidae, $\mathrm{GEO}=$ Geometridae, $\mathrm{ARC}=$ Arctiidae, $\mathrm{LYC}=$ Lycaenidae, $\mathrm{PAP}=$ Papilionidae, $\mathrm{SPH}=$ Sphingidae, $\mathrm{THY}=$ Thyatiridae, NOT $=$ Notodontidae. 
TABLE 3. Macrolepidopterous larvae collected from foliage of four host tree groups at the Fernow Experimental Forest, West Virginia.

Species are arranged from most to least abundant for the combined sampling years of 1989-1994. First and last collection dates are given.

\begin{tabular}{|c|c|c|c|c|c|c|c|c|}
\hline \multirow[b]{2}{*}{ Species $^{2,3}$} & \multirow[b]{2}{*}{ Family ${ }^{1}$} & \multicolumn{5}{|c|}{ No. per host tree } & \multicolumn{2}{|c|}{ Collection Dates } \\
\hline & & Birch $\mathrm{Cl}$ & herry 1 & Maple & Oak & Total & First & Last \\
\hline Lomographa glomeraria (Grt.) & GEO & 13 & 795 & 4 & 3 & 815 & 10MAY & $28 J U N$ \\
\hline Erannis tiliaria (Harr.) & GEO & 275 & 143 & 159 & 214 & 791 & 07MAY & $19 J U N$ \\
\hline Lomographa vestaliata $(\mathrm{Gn})$. & GEO & 7 & 664 & 7 & 7 & 685 & 30MAY & $15 \mathrm{AUG}$ \\
\hline Melanolophia canadaria (Gn.) & GEO & 106 & 323 & 134 & 77 & 640 & 07MAY & $15 \mathrm{AUG}$ \\
\hline Alsophila pometaria (Harr.) & GEO & 44 & 202 & 62 & 219 & 527 & 07MAY & 23JUN \\
\hline Orthosia hibisci (Gn.) & NOC & 217 & 108 & 23 & 107 & 455 & 07MAY & $28 \mathrm{JUN}$ \\
\hline Polia latex (Gn.) & NOC & 77 & 107 & 101 & 51 & 336 & 07JUN & $15 \mathrm{AUG}$ \\
\hline Itame pustularia (Gn.) & GEO & 0 & 5 & 287 & 2 & 294 & 07JUN & $15 \mathrm{AUG}$ \\
\hline Lymantria dispar (L.) & LYM & 28 & 12 & 48 & 201 & 289 & 07MAY & $29 J U N$ \\
\hline Hydria prunivorata (Fgn.) & GEO & 0 & 193 & 0 & 0 & 193 & $18 J U N$ & 13AUG \\
\hline Morrisonia confusa (Hbn.) & $\mathrm{NOC}$ & 46 & 77 & 21 & 17 & 161 & 29MAY & 15AUG \\
\hline Hydrelia inornata (Hulst) ${ }^{3}$ & GEO & 45 & 21 & 79 & 11 & 156 & 10MAY & 15AUG \\
\hline Phigalia titea (Cram.) & GEO & 30 & 33 & 22 & 68 & 153 & 07MAY & 13JUN \\
\hline Campaea perlata $(\mathrm{Gn})$. & GEO & 36 & 48 & 44 & 11 & 139 & 07MAY & $15 \mathrm{AUG}$ \\
\hline Orthosia rubescens (Wlk.) & NOC & 54 & 25 & 24 & 19 & 122 & 10MAY & 07JUL \\
\hline Eupsilia sidus $(\mathrm{Gn} .)^{2}$ & NOC & 99 & 1 & 2 & 12 & 114 & 07MAY & 07JUN \\
\hline $\begin{array}{l}\text { Amphipyra pyramidoides } \mathrm{Gn} \text {. } \\
\text { Lomographa semiclarata }\end{array}$ & NOC & 10 & 46 & 23 & 24 & 103 & 07MAY & $15 J U N$ \\
\hline (Wlk.) & GEO & 0 & 72 & 1 & 1 & 74 & 04JUN & 20JUL \\
\hline Hyphantria cunea (Drury) & ARC & 21 & 8 & 9 & 35 & 73 & 22MAY & 13AUG \\
\hline Eupsilia n. sp. ${ }^{2}$ & NOC & 20 & 15 & 7 & 24 & 66 & 10MAY & $10 \mathrm{JUN}$ \\
\hline $\begin{array}{l}\text { Symmerista leucitys Franc. } \\
\text { Halysidota tessellaris }\end{array}$ & NOT & 0 & 0 & 49 & 0 & 49 & $26 \mathrm{JUL}$ & 09AUG \\
\hline (J.E. Smith) & ARC & 7 & 10 & 7 & 20 & 44 & 02JUL & $15 \mathrm{AUG}$ \\
\hline Tetracis cachexiata $\mathrm{Gn}$. & GEO & 11 & 21 & 7 & 4 & 43 & 07MAY & $15 \mathrm{AUG}$ \\
\hline Lithophane hemina Grt. & NOC & 11 & 17 & 13 & 1 & 42 & 23MAY & 06JUL \\
\hline Hydrelia condensata (Wlk.) $)^{2}$ & GEO & 14 & 1 & 22 & 3 & 40 & $13 J U L$ & $10 \mathrm{AUG}$ \\
\hline Lochmaeus manteo Doubleday & NOT & 2 & 0 & 0 & 37 & 39 & 29JUN & 14AUG \\
\hline Peridea basitriens (Wlk.) & NOT & 1 & 0 & 38 & 0 & 39 & 05JUL & 14AUG \\
\hline Besma quercivoraria (Gn.) & GEO & 4 & 0 & 0 & 34 & 38 & 11MAY & 03AUG \\
\hline Phigalia strigataria $(\text { Minot })^{2}$ & GEO & 18 & 5 & 2 & 10 & 35 & 07MAY & $12 J U N$ \\
\hline Iridopsis larvaria $(\mathrm{Gn})$. & GEO & 1 & 33 & 0 & 0 & 34 & 04JUN & 03AUG \\
\hline Besma endropiaria (G. \& R.) & GEO & 0 & 3 & 26 & 5 & 34 & 01JUN & 10AUG \\
\hline Malacosoma disstria $\mathrm{Hbn}^{2}$ & LAS & 0 & 4 & 2 & 27 & 33 & 12MAY & $12 J U N$ \\
\hline Dryocampa rubicunda (F.) & SAT & 0 & 0 & 31 & 0 & 31 & 09JUL & 16JUL \\
\hline $\begin{array}{l}{ }^{1} \mathrm{GEO}=\text { Geometridae, } \mathrm{NOC}=\mathrm{No} \\
\text { Notodontidae, LYM = Lymantri } \\
\text { THY = Thyatiridae, PAP = Papil } \\
{ }^{2} \text { Species that were not collected } \\
{ }^{3} \text { Species collected on oak at Fern }\end{array}$ & $\begin{array}{l}\text { ctuidae, } \mathrm{A} \\
\text { idae, SAT }= \\
\text { ionidae, } \mathrm{N} \\
\text { at Coopers } \\
\text { low that } \mathrm{w}\end{array}$ & $\begin{array}{l}\text { ARC }=\text { Ar } \\
=\text { Saturn } \\
\text { NYM }=\text { N } \\
\text { rs Rock, }\end{array}$ & $\begin{array}{l}\text { rctiidae, } \\
\text { niidae, } \\
\text { Jymphal } \\
\text { 1984-19 } \\
\text { collect }\end{array}$ & $\begin{array}{l}\text { LAS = } \\
\text { DRE = } \\
\text { lidae, L } \\
985(B u \\
\text { ted in G }\end{array}$ & ler 199 & 2). & $\begin{array}{l}\text { NOT }= \\
=\text { Sphir }\end{array}$ & $\begin{array}{l}\text { Intinued } \\
\text { gidae, }\end{array}$ \\
\hline
\end{tabular}




\begin{tabular}{|c|c|c|c|c|c|c|c|c|}
\hline \multirow[b]{2}{*}{ Species } & \multirow[b]{2}{*}{ Family $^{1}$} & \multicolumn{5}{|c|}{ No. per host tree } & \multicolumn{2}{|c|}{ Collection Dates } \\
\hline & & Birch & Cherry & Maple & Oak & Total & First & Last \\
\hline \multicolumn{9}{|l|}{ Anavitrinella pampinaria } \\
\hline (Gn.) & GEO & 9 & 21 & 0 & 0 & 30 & 14MAY & $18 J U N$ \\
\hline Acronicta fragilis $\mathrm{Gn}$. & NOC & 19 & 7 & 2 & 0 & 28 & 04JUN & $14 \mathrm{AUG}$ \\
\hline Eupithecia miserulata Grt. & GEO & 0 & 19 & 6 & 1 & 26 & 29MAY & 25JUL \\
\hline \multicolumn{9}{|l|}{ Eupithecia herefordaria } \\
\hline $\begin{array}{l}\text { C. \& S. } \\
\text { Satyrium calanus (Hbn.) }\end{array}$ & GEO & 5 & 13 & 6 & 0 & 24 & 07JUN & $\begin{array}{l}\text { 05JUL } \\
25 \mathrm{MAY}\end{array}$ \\
\hline $\begin{array}{l}\text { Satyrium calanus (Hbn.) } \\
\text { Pseudothyatira }\end{array}$ & LYC & 0 & 0 & \\
\hline $\begin{array}{l}\text { Pseudothyatira } \\
\text { cymatophoroides (Gn.) }\end{array}$ & THY & 20 & 2 & 0 & 1 & 23 & 02JUL & 10AUG \\
\hline \multicolumn{9}{|l|}{ Hypagyrtis unipunctata } \\
\hline (Haw.) & GEO & 5 & 10 & 7 & 1 & 23 & 15MAY & 07AUG \\
\hline Heterocampa guttivitta (Wlk.) & NOT & 10 & 0 & 9 & 2 & 21 & 07JUN & 25JUL \\
\hline Probole amicaria (H.-S.) & GEO & 0 & 1 & 17 & 1 & 19 & 19JUN & 13AUG \\
\hline Zale minerea (Gn.) & NOC & 5 & 9 & 3 & 2 & 19 & 21MAY & 01AUG \\
\hline Drepana arcuata Wlk. & DRE & 17 & 0 & 0 & 0 & 17 & $11 \mathrm{JUN}$ & 07AUG \\
\hline Nadata gibbosa (J.E. Smith) & NOT & 0 & 0 & 0 & 17 & 17 & $18 J U N$ & $14 \mathrm{AUG}$ \\
\hline Achatia distincta $\mathrm{Hbn}$. & NOC & 6 & 6 & 0 & 3 & 15 & 29MAY & $27 \mathrm{JUN}$ \\
\hline \multicolumn{9}{|l|}{ Orgyia leucostigma } \\
\hline (J.E. Smith) & LYM & 1 & 8 & 3 & 3 & 15 & 17MAY & $16 \mathrm{JUL}$ \\
\hline Lithophane antennata (Wlk.) $)^{2}$ & NOC & 11 & 3 & 0 & 1 & 15 & 17MAY & 07JUN \\
\hline Ennomos subsignaria $(\mathrm{Hbn} .)^{2}$ & GEO & 0 & 0 & 6 & 8 & 14 & 21MAY & $26 J U N$ \\
\hline Acronicta ovata Grt. & NOC & 2 & 0 & 0 & 11 & 13 & $12 \mathrm{JUL}$ & $11 \mathrm{AUG}$ \\
\hline Paonias myops (J.E. Smith) ${ }^{3}$ & SPH & 1 & 7 & 0 & 4 & 12 & 06JUL & $10 \mathrm{AUG}$ \\
\hline Acronicta hasta $\mathrm{Gn}$. & NOC & 3 & 5 & 2 & 0 & 10 & 06JUL & $14 \mathrm{AUG}$ \\
\hline Orthosia alurina $(\mathrm{Sm} .)^{2}$ & NOC & 2 & 3 & 5 & 0 & 10 & $14 \mathrm{MAY}$ & $20 J U N$ \\
\hline Crocigrapha normani (Grt.) & NOC & 3 & 6 & 1 & 0 & 10 & 24MAY & $27 \mathrm{JUN}$ \\
\hline Bomolocha baltimoralis (Gn.) & NOC & 3 & 4 & 3 & 0 & 10 & 11JUL & 02AUG \\
\hline Parallelia bistriaris $\mathrm{Hbn}$. & NOC & 1 & 0 & 9 & 0 & 10 & $15 \mathrm{MAY}$ & 10AUG \\
\hline Anisota virginiensis (Drury) & SAT & 0 & 0 & 0 & 9 & 9 & 09JUL & 09JUL \\
\hline Acronicta americana (Harr.) $)^{3}$ & NOC & 3 & 3 & 2 & 1 & 9 & 09JUL & $15 \mathrm{AUG}$ \\
\hline Catocala ultronia $(\mathrm{Hbn} .)^{2}$ & NOC & 0 & 8 & 0 & 0 & 8 & $25 \mathrm{MAY}$ & 01JUN \\
\hline Biston betularia (L.) & GEO & 3 & 4 & 0 & 0 & 7 & 02JUL & $24 \mathrm{JUL}$ \\
\hline \multicolumn{9}{|l|}{ Eutrapela clemataria } \\
\hline (J.E. Smith) & GEO & 0 & 3 & 3 & 1 & 7 & $29 \mathrm{MAY}$ & $23 J U N$ \\
\hline Malacosoma americanum (F.) & LAS & 0 & 6 & 0 & 1 & 7 & 24MAY & $13 \mathrm{JUN}$ \\
\hline \multicolumn{9}{|l|}{ Symmerista albifrons } \\
\hline (J.E. Smith $)^{2}$ & NOT & 0 & 0 & 0 & 7 & 7 & $26 \mathrm{JUL}$ & 02AUG \\
\hline Cleora sublunaria $(\mathrm{Gn} .)^{2}$ & GEO & 0 & 4 & 2 & 1 & 7 & 26MAY & 05JUN \\
\hline Cladara atroliturata (Wlk. $)^{3}$ & GEO & 3 & 1 & 2 & 1 & 7 & 07JUN & $23 J U N$ \\
\hline Lithophane laticinerea Grt. $^{2}$ & NOC & 0 & 4 & 0 & 3 & 7 & 17MAY & $22 J U N$ \\
\hline Papilio glaucus $\mathrm{L}^{3}$ & PAP & 0 & 6 & 0 & 0 & 6 & 28JUN & $24 \mathrm{JUL}$ \\
\hline Colocasia propinquilinea (Grt.) & ) $\mathrm{NOC}$ & 4 & 0 & 2 & 0 & 6 & 25JUN & 21JUL \\
\hline \multicolumn{9}{|c|}{ Lithophane innominata } \\
\hline$(\mathrm{Sm} .)^{2,3}$ & NOC & 2 & 0 & 2 & 2 & 6 & 07JUN & $14 \mathrm{JUN}$ \\
\hline Lithophane querquera Grt. $^{2}$ & NOC & 2 & 0 & 0 & 4 & 6 & 14MAY & 05JUN \\
\hline Eupsilia morrisoni (Grt.) & $\mathrm{NOC}$ & 1 & 0 & 0 & 5 & 6 & 07MAY & 22MAY \\
\hline
\end{tabular}




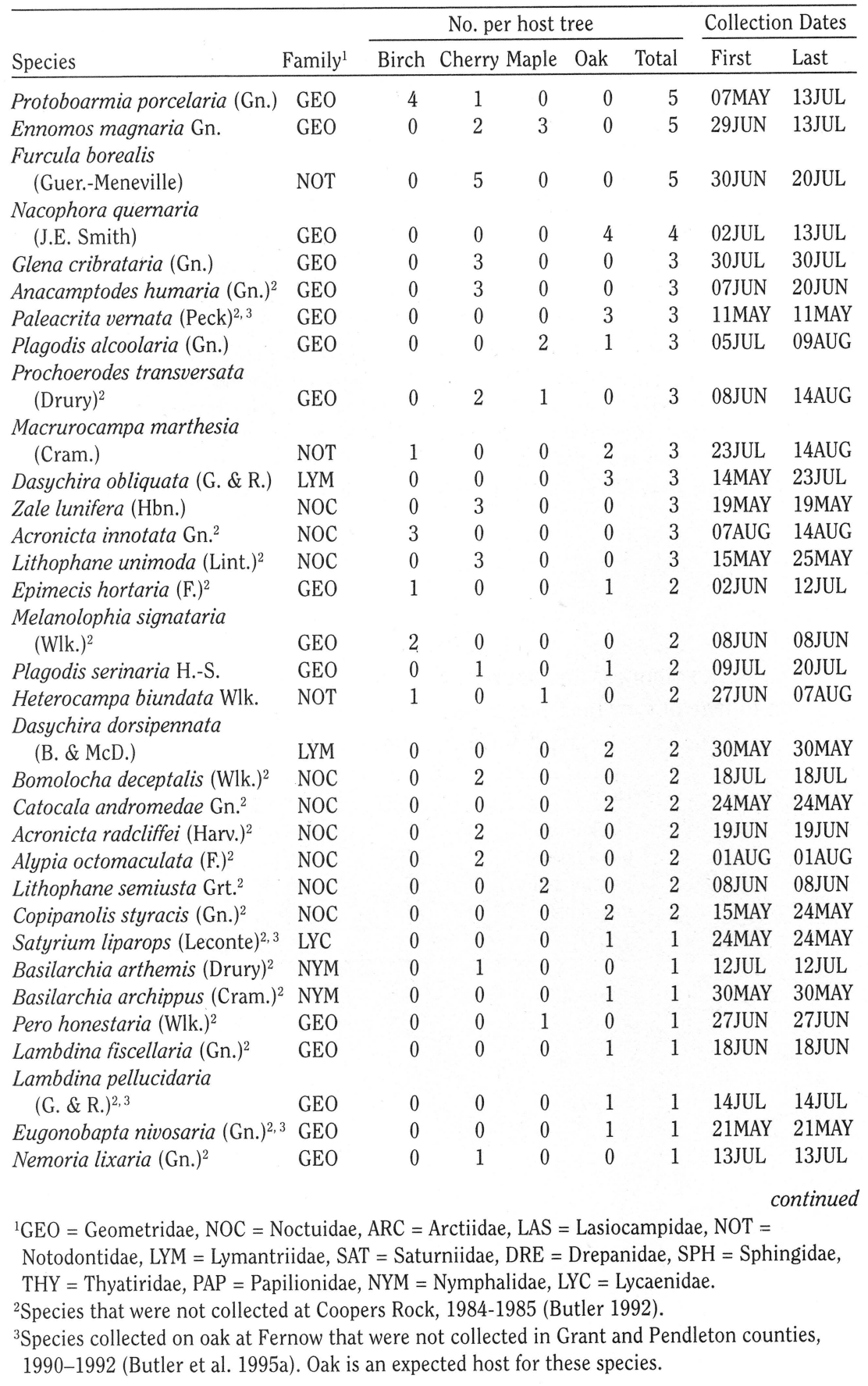




\begin{tabular}{|c|c|c|c|c|c|c|c|c|}
\hline \multirow[b]{2}{*}{ Species } & \multirow[b]{2}{*}{ Family $^{1}$} & \multicolumn{5}{|c|}{ No. per host tree } & \multicolumn{2}{|c|}{ Collection Dates } \\
\hline & & Birch & Cherry & Maple & Oak & Total & First & Last \\
\hline Actias luna $(\text { L. })^{3}$ & SAT & 0 & 0 & 0 & 1 & 1 & 09AUG & 09AUG \\
\hline Peridea angulosa (J.E. Smith) & NOT & 0 & 0 & 0 & 1 & 1 & 31JUL & 31JUL \\
\hline Schizura unicornis (J.E. Smith) & n) NOT & 0 & 0 & 1 & 0 & 1 & $14 \mathrm{AUG}$ & $14 \mathrm{AUG}$ \\
\hline \multicolumn{9}{|c|}{ Oligocentria semirufescens } \\
\hline (Wlk.) & NOT & 0 & 1 & 0 & 0 & 1 & 09AUG & 09AUG \\
\hline Orgyia definita Pack. ${ }^{2}$ & LYM & 0 & 1 & 0 & 0 & 1 & $28 \mathrm{JUN}$ & $28 \mathrm{JUN}$ \\
\hline Acronicta lobeliae $\mathrm{Gn}^{2}$ & NOC & 0 & 0 & 0 & 1 & 1 & $28 J U N$ & $28 J U N$ \\
\hline Acronicta haesitata (Grt. $)^{2}$ & NOC & 0 & 1 & 0 & 0 & 1 & 17JUL & $17 \mathrm{JUL}$ \\
\hline Lithophane grotei Riley & NOC & 0 & 0 & 0 & 1 & 1 & 24MAY & 24MAY \\
\hline
\end{tabular}

${ }^{1} \mathrm{GEO}=$ Geometridae, $\mathrm{NOC}=$ Noctuidae, $\mathrm{ARC}=$ Arctiidae, $\mathrm{LAS}=$ Lasiocampidae, NOT $=$

Notodontidae, $\mathrm{LYM}=$ Lymantriidae, $\mathrm{SAT}=$ Saturniidae, $\mathrm{DRE}=$ Drepanidae, $\mathrm{SPH}=$ Sphingidae, $\mathrm{THY}=$ Thyatiridae, $\mathrm{PAP}=$ Papilionidae, $\mathrm{NYM}=$ Nymphalidae, $\mathrm{LYC}=$ Lycaenidae.

${ }^{2}$ Species that were not collected at Coopers Rock, 1984-1985 (Butler 1992).

${ }^{3}$ Species collected on oak at Fernow that were not collected in Grant and Pendleton counties, 1990-1992 (Butler et al. 1995a). Oak is an expected host for these species.

TABLE 4.

Species richness and abundance of macrolepidopterous larvae on foliage of four host tree groups at Fernow Experimental Forest, West Virginia, 1989-1994.

\begin{tabular}{lcc}
\hline Host & Richness & Abundance \\
\hline black birch & 57 & 1,350 \\
black cherry & 71 & 3,188 \\
mixed maple & 57 & 1,352 \\
mixed oak & 72 & 1,387 \\
\hline TOTAL & 111 & 7,277 \\
\hline
\end{tabular}




\section{Blank Page in Original Bulletin}


